\title{
APLIKASI KONSELING ISLAMI PADA ANAK USIA DINI
}

\author{
Tarsono \\ Fakultas Psikologi UIN Sunan Gunung Djati Bandung, Jl. A.H Nasution No. 105 Bandung \\ email: tarsonomakmuri@yahoo.com
}

\begin{abstract}
Abstrak
Salah satu tujuan Pendidikan Anak Usia Dini adalah meningkatkan kemampuan keimanan, kepribadian dan membiasakan beribadah sehari-hari. Mengingat tujuan dalam pendidikan tersebut, maka penelitian ini difokuskan kedalam permasalahan apakah orang tua dan guru sudah dapat membantu meningkatkan keimanan anak Taman kanak-Kanak. Layanan konseling Islami di Taman Kanak-Kanak belum terprogram secara spesifik. Penerapan layanan konselingnya masih terintegrasi dalam program keagamaan. Usaha dalam membantu anak Taman Kanak-kanak dalam menanamkan moral nilai keagamaan, ini sangat penting. Adapun salah satu masalah yang dirasakan sangat penting adalah belum tersusunnya program penanaman moral nilai-nilai keagamaan di Taman kanak-kanak secara khusus yang meliputi 1) dasar-dasar keimanan kepada Allah SWT, 2) dasar-dasar kepribadian, dan 3) kebiasaan anak dalam beribadah sehari-hari. Temuan penelitian ini menunjukkan, terdapat beberapa siswa Taman kanak-kanak belum dapat melakukan sholat lima waktu secara tepat sesuai dengan ketentuan, baik bacaan atau gerakan sholatnya. Bantuan yang diberikan oleh orang tua kepada siswa TK adalah mengajak sholat berjamaah, mengundang guru ngaji, memberikan bantuan lewat media. Bantuan yang diberikan oleh guru adalah adalah membuat jadwal sholat berjamaah, membuat alat peraga tentang sholat.
\end{abstract}

Kata kunci : penanaman moral, nilai-nilai agama, pendidikan, anak usia dini

\section{Abstract}

Young learner education aims to increase belief, personality, and daily worship. This research focus on parents and teachers roles increasing belief of children in kindergarten. Islamic counseling in kindergarten is not spesifically programmed since it is still integrated with religion program. Applying moral and religious values is considered important including 1) basic belief to Allah SWT, 2) basic personality, and 3) children habit in daily worship. Result shows that some children in kindergarten have not applied daily worship appropriately. Parents support are asking praying together, inviting religion teacher, and providing media. Teacher can make schedule for praying together and making media of praying.

Keyword : applying moral values, religion values, education, young learners

\section{PENDAHULUAN}

Salah satu sikap dasar yang harus dimiliki seorang anak untuk menjadi seorang manusia yang baik dan benar adalah memiliki sikap dan nilai moral keagamaan yang baik da- lam berperilaku sebagai makhluk Allah, anak, anggota keluarga dan anggota masyarakat.

Imam al-Ghazali mengatakan, "Anak-anak kita laksana batu permata." Kita mugkin akan berkomentar, "tetapi banyak orang dewasa yang jadi pandai besi (bukan ahli mengukir batu jadi permata)." Karena itu mereka memer- 
lukan petunjuk dan pengarahan bagaimana cara membimbing anak-anaknya.

Ibnu Qayyim dalam Hasan Syamsi Pasya (2010:1) mengingatkan pentingnya peranan keluarga dalam pendidikan. Ia menguraikan, bahwa "dalam banyak kasus, kerusakan anakanak muda disebabkan kelalaian orang-tuanya. Mereka tidak mengajarkan pokok-pokok ajaran agama dan sunah-sunahnya. Mereka menyia-nyiakan anaknya ketika masih kecil. Akhirnya mereka tidak mendapatkan kebaikan apapun dari anak-anaknya. Sebaliknya anak tidak dapat memperoleh kebaikan dari orang tuanya ketika mereka beranjak dewasa"

Sebagaimana Allah Swt berfirman dalam al-qur'an surat at-tahriim ayat 6 , yang artinya:

Hai orang-orang yang beriman, peliharalah dirimu dan keluargamu dari api neraka yang bahan bakarnya adalah manusia dan batu; penjaganya malaikat-malaikat yang kasar, keras, dan tidak mendurhakai Allah terhadap apa yang diperintahkan-Nya kepada mereka dan selalu mengerjakan apa yang diperintahkan.

Memahami karakter anak, adalah salah satu cara ampuh untuk membina kepribadian anak, memupuk kecerdasannya, mempertajam nalarnya, dan mengasah bakatnya. Akan tetapi, cara ini tidak akan efektif dan tidak berati apaapa jika orang tua tidak memulainya terlebih dahulu dari diri mereka sendiri. Keteladanan dan contoh yang baik akan membuat anak lebih mudah menerima dan mencerna apa kehendak orantuanya, bahkan, tak jarang seorang anak melakukan sesuatu bukan karena disuruh orangtuanya, melainkan karena melihat orangtuanya melakukan hal tersebut. Abdullah (20 02:1)

Fitrah menurut pandangan Islam adalah sifat-sifat Allah yang ditiupkan Allah kepada manusia sebelum lahir. Pendidikan Islam bertugas mengembangkan sehabis-habisnya fitrah tersebut kearah tujuan pendidikan yaitu ibadah. Ibadah merupakan tujuan tertinggi dalam tujuan pendidikan Islam. Perkembangan spiritual (ruh), kebebasan kemauan dan akal ('aql) adalah aspek-aspek lain yang perlu dikembangkan disamping perkembangan jasmani dan mental.

Tujuan pendidikan Islam, konstitusi kita dengan sangat jelas memaparkan tujuan pendidikan nasional melalui UU tentang Sisdiknas nomor 20 tahun 2003 Pasal 3 “... berkembang- nya potensi peserta didik agar menjadi manusia yang beriman dan bertakwa kepada Tuhan Yang Maha Esa, berakhlak mulia, sehat, berilmu, cakap, kreatif, mandiri, dan menjadi warga negara yang demokratis serta bertanggung jawab."

Pendidikan adalah proses pembimbingan dan pimpinan secara sadar oleh pendidik terhadap perkembangan jasmani dan rohani anak didik menuju terbentuknya kepribadian yang utama. Marimba (1980 : 19). Ahmad Tafsir mencoba mendefinikan pendidikan secara luas yakni pendidikan adalah usaha meningkatkan diri dalam segala aspeknya. Ahmad Tafsir (1995 : 6). Pendapat Ahmad Tafsir nampaknya lebih melihat bahwa manusia sebetulnya memiliki kemampuan untuk dapat mendewasakan dirinya sendiri disamping melalui bimbingan orang lain untuk mencapai tujuan hidup yang diharapkan.

Usia Taman kanak-kanak adalah saat yang paling baik bagi guru Taman kanak-kanak, untuk meletakkan dasar-dasar Pendidikan nilai, moral dan agama kepada anak Taman kanak-kanak. Walaupun peran orang tua sangatlah besar dalam membangun dasar moral dan agama bagi anak-anaknya, peran guru Taman kanak-kanak juga tidaklah kecil dalam meletakkan dasar moral dan agama bagi seorang anak, karena biasanya anak-anak Taman kanak-kanak senang menuruti perintah gurunya.

Oleh karena itu, seorang guru Taman kanak-kanak harus selalu berupaya dengan berbagai cara agar dapat membimbing anak seusia Taman kanak-kanak agar mempunyai kepribadian yang baik, yang dilandasi dengan nilai moral dan agama. Dengan diberikannya lan

dasan pendidikan moral dan agama kepada anak Taman Kanak-kanak, seorang anak Taman Kanak-kanak dapat belajar membedakan perilaku yag benar dan salah. Contohnya, di Taman Kanak-kanak seorang anak Taman Kanak-kanak dapat belajar bahwa mereka tidak boleh menjadi anak yang senang berbohong, mengambil barang yang bukan miliknya atau mengganggu orang lain. Satibi (2008:4).

Taman kanak-kanak Islam Terpadu alMukhlisin Kabupaten Indramayu dengan siswa yang rata-rata berusia antara $3-6$ tahun, sudah banyak yang mampu melakukan kegiatan keagamaan seperti melaksanakan wudlu sesuai aturan, melaksanakan sholat lima waktu, belajar 
menunaikan zakat, shodaqoh, mampu menyebutkan nama-nama Allah dan rasulnya, mampu mengucapkan salam kepada kedua orang tua, guru dan juga kepada teman-temannya.

Usaha dalam membantu anak Taman Kanak-kanak Islam Terpadu al-Mukhlisin Kabupaten Indramayu dalam menanamkan moral nilai keagamaan, ini merupakan sangat penting. Adapun salah satu masalah yang dirasakan sangat penting adalah belum tersusunnya program penanaman moral nilai-nilai keagamaan di Taman kanak-kanak secara khusus yang meliputi 1) dasar-dasar keimanan kepada Allah SWT, 2) dasar-dasar kepribadian, dan 3) kebiasaan anak dalam beribadah sehari-hari.

Sesuai dengan temuan di lapangan ketika penulis melakukan observasi kepada orang tua dari anak Taman kanak-kanak dalam hal penanaman moral nilai-nilai keagamaan, maka bimbingan dari orang tua memiliki pengaruh yang cukup besar dalam menumbuhkan kesadaran anak Taman Kanak-kanak dalam melaksanakan penanaman moral nilai-nilai keagamaan yang meliputi keimanan, kepribadian dan kebiasaan beribadah anak Taman Kanakkanak.

\section{TINJAUAN TEORI}

\section{Pengertian AUD}

Pendidikan anak usia dini (PAUD) adalah jenjang pendidikan sebelum jenjang pendidikan dasar yang merupakan suatu upaya pembinaan yang ditujukan bagi anak sejak lahir sampai dengan usia enam tahun yang dilakukan melalui pemberian rangsangan pendidikan untuk membantu pertumbuhan dan perkembangan jasmani dan rohani agar anak memiliki kesiapan dalam memasuki pendidikan lebih lanjut, yang diselenggarakan pada jalur formal, nonformal, dan informal.

Pendidikan anak usia dini merupakan salah satu bentuk penyelenggaraan pendidikan yang menitikberatkan pada peletakan dasar ke arah pertumbuhan dan perkembangan fisik (koordinasi motorik halus dan kasar), kecerdasan (daya pikir, daya cipta, kecerdasan emosi, kecerdasan spiritual), sosio emosional (sikap dan perilaku serta agama) bahasa dan komunikasi, sesuai dengan keunikan dan tahaptahap perkembangan yang dilalui oleh anak usia dini.

Ada dua tujuan diselenggarakannya pendidikan anak usia dini yaitu: 1). tujuan utama: untuk membentuk anak Indonesia yang berkualitas, yaitu anak yang tumbuh dan berkembang sesuai dengan tingkat perkembangannya sehingga memiliki kesiapan yang optimal di dalam memasuki pendidikan dasar serta mengarungi kehidupan di masa dewasa. 2) tujuan penyerta: untuk membantu menyiapkan anak mencapai kesiapan belajar (akademik) di sekolah.

Rentangan anak usia dini menurut Pasal 28 UU Sisdiknas No.20/2003 ayat 1 adalah 0-6 tahun. Sementara menurut kajian rumpun keilmuan PAUD dan penyelenggaraannya di beberapa negara, PAUD dilaksanakan sejak usia 0-8 tahun.

Ruang Lingkup Pendidikan Anak Usia Dini adalah (1) Infant (0-1 tahun); (2) Toddler (2 - 3 tahun); (3) Preschool/Kindergarten Children (3-6 tahun); dan (4) Early Primary School (SD Kelas Awal) (6-8 tahun).

\section{Karakteristik AUD}

Anak usia dini $(0-8$ tahun $)$ adalah individu yang sedang mengalami proses pertumbuhan dan perkembangan yang sangat pesat. Bahkan dikatakan sebagai lompatan perkembangan karena itulah maka usia dini dikatakan sebagai golden age (usia emas) yaitu usia yang sangat berharga dibanding usia-usia selanjutnya. Usia tersebut merupakan fase kehidupan yang unik. Secara lebih rinci akan diuraikan karakteristik anak usia dini sebagai berikut :

Usia $0-1$ tahun. Pada masa bayi perkembangan fisik mengalami kecepatan luar biasa, paling cepat dibanding usia selanjutnya. Berbagai kemampuan dan keterampilan dasar dipelajari anak pada usia ini. Beberapa karakteristik anak usia bayi dapat dijelaskan antara lain :

a) Mempelajari keterampilan motorik mulai dari berguling, merangkak, duduk, berdiri dan berjalan. b) Mempelajari keterampilan menggunakan panca indera, seperti melihat atau mengamati, meraba, mendengar, mencium dan mengecap dengan memasukkan setiap benda ke mulutnya. c) Mempelajari komunikasi sosial. Bayi yang baru lahir telah siap melaksanakan kontrak sosial dengan lingkungannya. Komunikasi responsif dari orang dewasa akan mendorong dan memperluas respon verbal dan non verbal bayi. Berbagai kemampuan dan ketrampilan dasar tersebut merupakan modal penting bagi anak untuk menjalani proses perkembangan selanjutnya. 
Usia 2 - 3 tahun. Anak pada usia ini memiliki beberapa kesamaan karakteristik dengan masa sebelumnya. Secara fisik anak masih mengalami pertumbuhan yang pesat. Beberapa karakteristik khusus yang dilalui anak usia 2-3 tahun antara lain :

a) Anak sangat aktif mengeksplorasi benda-benda yang ada di sekitarnya. Ia memiliki kekuatan observasi yang tajam dan keinginan belajar yang luar biasa. Eksplorasi yang dilakukan oleh anak terhadap benda-benda apa saja yang ditemui merupakan proses belajar yang sangat efektif. Motivasi belajar anak pada usia tersebut menempati grafik tertinggi dibanding sepanjang usianya bila tidak ada hambatan dari lingkungan. b) Anak mulai mengembangkan kemampuan berbahasa. Diawali dengan berceloteh, kemudian satu dua kata dan kalimat yang belum jelas maknanya. Anak terus belajar dan berkomunikasi, memahami pembicaraan orang lain dan belajar mengungkapkan isi hati dan pikiran. c) Anak mulai belajar mengembangkan emosi. Perkembangan emosi anak didasarkan pada bagaimana lingkungan memperlakukan dia. Sebab emosi bukan ditemukan oleh bawaan namun lebih banyak pada lingkungan.

Usia $4-6$ tahun. Anak usia $4-6$ tahun memiliki karakteristik antara lain:

a) Berkaitan dengan perkembangan fisik, anak sangat aktif melakukan berbagai kegiatan. Hal ini bermanfaat untuk mengembangkan otot-otot kecil maupun besar. b) Perkembangan bahasa juga semakin baik. Anak sudah mampu memahami pembicaraan orang lain dan mampu mengungkapkan pikirannya dalam batasbatas tertentu. c) Perkembangan kognitif (daya pikir) sangat pesat, ditunjukkan dengan rasa ingin tahu anak yang luar biasa terhadap lingkungan sekitar. Hal itu terlihat dari seringnya anak menanyakan segala sesuatu yang dilihat. d) Bentuk permainan anak masih bersifat individu, bukan permainan sosial. Walaupun aktifitas bermain dilakukan anak secara bersama.

Usia 7 - 8 tahun. Karakteristik perkembangan anak usia $7-8$ tahun antara lain :

a) Perkembangan kognitif anak masih berada pada masa yang cepat. Dari segi kemampuan, secara kognitif anak sudah mampu berpikir bagian per bagian. Artinya anak sudah mampu berpikir analisis dan sintesis, deduktif dan induktif. b) Perkembangan sosial anak mu lai ingin melepaskan diri dari otoritas orangtuanya. Hal ini ditunjukkan dengan kecende- rungan anak untuk selalu bermain di luar rumah bergaul dengan teman sebaya. c) Anak mulai menyukai permainan sosial. Bentuk permainan yang melibatkan banyak orang dengan saling berinteraksi. d) Perkembangan emosi anak sudah mulai berbentuk dan tampak sebagai bagian dari kepribadian anak. Walaupun pada usia ini masih pada taraf pembentukan, namun pengalaman anak sebenarnya telah menampakkan hasil

\section{Faktor yang mempengaruhi perkembangan AUD}

Banyak hal yang dapat mempengaruhi kondisi anak usia dini, secara garis besar dapat dikelompokkan menjadi dua yaitu:

Faktor bawaan, adalah faktor yang diturunkan dari kedua orangtuanya, baik yang bersifat fisik maupun psikis. Faktor bawaan lebih dominan dari pihak ayah daripada ibu atau sebaliknya. Faktor ini tidak dapat direkayasa oleh orangtua yang menurunkan. Dan hanya ditentukan oleh waktu satu detik, yaitu saat bertemunya sel sperma dan ovum. Oleh karena itu, saat ovulasi merupakan saat paling berharga untuk sepanjang hidup manusia, karena pada saat itulah diturunkan sifat bawaan yang akan terbawa sepanjang usia manusia.

Faktor lingkungan, yaitu faktor yang berasal dari luar faktor bawaan, meliputi seluruh lingkungan yang dilalui oleh anak. Lingkungan dapat dipisahkan menjadi dua, yaitu lingkungan dalam kandungan dan lingkungan di luar kandungan.

Lingkungan dalam kandungan sangat penting bagi perkembangan anak. Karena perkembangan janin dalam kandungan mengalami kecepatan luar biasa, lebih cepat 200.000 kali dibanding perkembangan sesudah lahir. Oleh karena itu lingkungan yang positif dalam kandungan akan berpengaruh positif bagi perkembangan janin, demikian juga sebaliknya.

Lingkungan di luar kandungan, juga besar pengaruhnya terhadap perkembangan anak usia dini. Sebab anak menjadi bagaimana seorang anak sangat dipengaruhi oleh bagaimana lingkungan memperlakukan dia. Lingkungan luar kandungan dibedakan menjadi tiga hal yaitu :

a) Lingkungan keluarga, yaitu lingkungan yang dialami anak dalam berinteraksi dengan anggota keluarga baik interaksi secara langsung maupun tidak langsung. Lingkungan keluarga khususnya dialami anak usia 0 - 3 ta- 
hun. Usia ini menjadi landasan bagi anak untuk melalui proses selanjutnya. b). Lingkungan masyarakat atau lingkungan teman sebaya. Seiring bertambahnya usia, anak akan mencari teman untuk berinteraksi dan bermain bersama. Kondisi teman sebaya turut menentukan bagaimana anak jadinya. c). Lingkungan sekolah. Pada umumnya anak akan memasuki lingkungan sekolah pada usia 4 - 5 tahun atau bahkan yang 3 tahun. Lingkungan di sekolah besar pengaruhnya terhadap perkembangan anak. Sekolah yang baik akan mampu berperan secara baik dengan memberi kesempatan dan mendorong anak untuk mengaktualisasikan diri sesuai dengan kemampuan yang sesungguhnya.

\section{Pola Perkembangan AUD}

Perkembangan setiap anak memiliki pola yang sama, walaupun kecepatannya berbeda. Setiap anak mengikuti pola yang dapat diramalkan dengan cara dan kecepatannya sendiri. Sebagian anak berkembang dengan tertib tahap demi tahap, langkah demi langkah. Namun sebagian yang lain mengalami kecepatan melonjak. Di samping itu ada juga yang mengalami penyimpangan atau keterlambatan. Namun secara umum setiap anak berkembang dengan mengikuti pola yang sama. Beberapa pola tersebut antara lain :

Pertama, Perkembangan fisik mengikuti hukum perkembangan yang disebut "cephalocaudal" dan "proximodistal". Hukum cephalocaudal menyatakan bahwa perkembangan dimulai dari kepala kemudian menyebar ke seluruh tubuh sampai ke kaki. Sedangkan hukum proximodistal menyatakan bahwa perkembangan bergerak dari pusat sumbu ke ujungujungnya atau dari bagian yang dekat sumbu pusat tubuh ke bagian yang lebih jauh.

Kedua, perkembangan bergerak dari tanggapan umum menuju ke tanggapan khusus. Bayi pada awal perkembangan memberikan reaksi dengan menggerakkan seluruh tubuh. Semakin lama ia akan mampu memberikan reaksi dalam bentuk gerakan khusus. Demikian seterusnya dalam hal-hal lain.

Ketiga, perkembangan berlangsung secara berkesinambungan. Proses perkembangan diawali dari bertemunya sel sperma dan ovum yang disebut ovulasi, dan terus secara berkesinambungan hingga kematian. Kadang perlahan, kadang cepat, kadang maju terus, kadang sejenak mundur. Satu tahap perkembangan menjadi landasan bagi tahap perkembangan se- lanjutnya. Tidak ada pengalaman anak yang sia-sia atau hilang terhapus. Hanya tertutupi oleh pengalaman-pengalaman berikutnya.

Keempat, terhadap periode keseimbangan dan tidak keseimbangan. Setiap anak mengalami periode dimana ia merasa bahagia, mudah menyesuaikan diri dan lingkungannya pun bersikap positif terhadapnya. Namun juga ada masa ketidakseimbangan yang ditandai dengan kesulitan anak untuk menyesuaikan diri, sulit diatur, emosi negatif dan sebagainya. Pola tersebut bila digambarkan ibarat spiral yang bergerak melingkar dengan jangka waktu kurang lebih 6 bulan, hingga akhirnya anak menemukan ketenangan dan jati diri.

Kelima, terhadap tugas perkembangan yang harus dilalui anak dari waktu ke waktu. Tugas perkembangan adalah sesuatu yang harus dilakukan atau dicapai oleh anak berdasarkan tahap usianya. Tugas perkembangan bersifat khas, sesuai dengan tuntutan dan ukuran yang berlaku di masyarakat. Misalnya bayi lahir dia akan melaksanakan tugas perkembangan berguling, tengkurap, duduk, berdiri, berjalan, bermain dan seterusnya. Kualitas dan kuantitas tugas perkembangan antara satu daerah berbeda dengan daerah lain.

\section{Cara Belajar AUD}

Anak pada usia dini (0 - 8 tahun) memiliki kemampuan belajar yang luar biasa. Khususnya pada masa kanak-kanak awal. Keinginan anak untuk belajar menjadikan ia aktif dan eksploratif. Anak belajar dengan seluruh panca inderanya untuk dapat memahami sesuatu, dan dalam waktu singkat ia akan beralih ke hal lain untuk dipelajari. Lingkungan lah yang kadang menjadikan anak terhambat dalam mengembangkan kemampuan belajarnya. Bahkan seringkali lingkungan mematikan keinginannya untuk bereksplorasi.

Cara belajar anak mengalami perkembangan seiring dengan bertambahnya usia. Secara garis besar dapat diuraikan cara belajar anak usia dini mulai dari awal perkembangan.

Usia 0 - 1 tahun. Anak belajar dengan mengendalikan kemampuan panca inderanya. Yakni pendengaran, penglihatan, penciuman, peraba dan perasa. Secara bertahap panca indera anak difungsikan lebih sempurna. Hingga usia satu tahun anak ingin mempelajari apa saja yang dilihat dengan mengarahkan seluruh panca indera. Hal itu nampak pada aktivitas 
anak memasukkan segala macam benda ke dalam mulut sebagai bagian dari proses belajar.

Usia 2 - 3 tahun. Anak melakukan proses belajar dengan lebih sungguh-sungguh. Ia memperhatikan apa saja yang ada di lingkungannya untuk kemudian ditiru. Jadi cara belajar anak yang utama pada usia ini adalah meniru. Meniru segala hal yang ia lihat dan ia dengar. Selain itu perkembangan bahasa anak pada usia tersebut sudah mulai berkembang. Anak mengembangkan kemampuan berbahasa juga dengan cara meniru.

Usia 4 - 6 tahun. Kemampuan bahasa anak semakin baik. Begitu anak mampu berkomunikasi dengan baik maka akan segera diikuti proses belajar anak dengan cara bertanya. Anak akan menanyakan apa saja yang ia saksikan. Pertanyaan yang tiada putus. Saat demikian kognisi anak berkembang pesat dan keinginan anak untuk belajar semakin tinggi. Anak belajar melalui bertanya dan berkomunikasi.

Usia 7 - 8 tahun. Perkembangan anak dari berbagai aspek sudah semakin baik. Walau demikian proses perkembangan anak masih terus berlanjut. Anak melakukan proses belajar dengan cara yang semakin kompleks. Ia menggunakan panca inderanya untuk menangkap berbagai informasi dari luar. Anak mulai mampu membaca dan berkomunikasi secara luas. Hal itu menjadi bagian dari proses belajar anak.

\section{Perilaku Keagamaan AUD}

Perilaku Keagamaan. Perilaku adalah cerminan kepribadian seseorang yang tampak dalam perbuatan dan interaksi terhadap orang lain dalam lingkungan sekitarnya. Perilaku merupakan internalisasi nilai-nilai yang diserap oleh seseorang selama proses berinteraksi dengan orang di luar dirinya. Perilaku seseorang menunjukkan tingkat kematangan emosi, moral, agama, sosial, kemandirian dan konsep dirinya. Maka perilaku manusia terbentuk selama proses perjalanan kehidupannya.

Perilaku anak usia dini pada masa ini sedang dalam pembentukan, selain karena faktor genetik, lingkungan sangat berpengaruh dalam pembentukan kepribadiannya. Anak usia dini bersifat imitatif atau peniru, apa yang ia lihat, rasakan dan lihat dari lingkungannya akan diikutinya karena ia belum mengetahui batasan benar dan salah, baik dan buruk, serta pantas dan tidak pantas. Anak masih belajar coba-ra- lat berperilaku yang dapat diterima oleh lingkungannya.

Oleh karena itu, masa usia dini adalah masa yang peka untuk menerima pengaruh dari lingkungannya. Hal ini merupakan kesempatan bagi lingkungan, dalam hal ini orang-tua gurusekolah, untuk memberikan pengaruh edukatif seluas-luasnya kepada anak, agar membantu mengembangkan perilaku anak yang positif.

Pada anak, perilaku dapat terbentuk melalui kebiasaan sehari-hari secara non-formal. Artinya, suatu perbuatan yang dilakukan atas anjuran orangg dewasa ataupun perilaku orang dewasa yang sengaja ditujukan kepada anak untuk diikuti. Dalam pendidikan anak usia dini, hal ini dapat dilakukan, misalnya berdoa bersama, mencuci tangan, berbagi dalam bermain, menjaga kebersihan, bersikap sopan-santun, mengucapkan terima-kasih, maaf-permisi. Win da Gunarti (2008:3-5).

Disonansi Moral. Menurut satibi (2008: 3.5) disonansi dipakai dalam pendidikan khususnya yang terkait dengan pendidikan nilai, norma, dan moral. Selain istilah tersebut anda akan kenal juga istilah resonansi. Kedua istilah tersebut secara sepintas terlihat kontradiktif, namun kedua istilah tersebut sebenarnya merupakan pasangan istilah yang saling melengkapi. Disonansi menekankan pada pengurangan/ penurunan gema atau getar ajaran nilai, norma dan moral yang ada pada diri seseorang. Sedangkan resonansi justru mengukuhkan/ menekankan adanya gema atau getar nilai, norma dan moral yang telah diketahui seseorang dari proses pendidikan sebelumnya.

Disonansi yang berati gema atau echo, ada pada diri manusia bersifat melemahkan suara hati dan prinsip, serta keyakinan dalam proses pendidikan, maupun dalam kehidupan. Hal ini selalu ada bahkan sering timbul dan cukup kuat keberadannya. (Kosasih Dj.: 1996).

Lebih lanjut Satibi (2008: 3.13) mengatakan bahwa ada 4 faktor yang menyebabkan munculnya disonansi pada diri manusia, yaitu :

a). Disonansi Kognitif. Dorongan yang muncul dari pemahaman ilmu atau pengetahuan yang sangat mantap, kuat serta komprehensif yang dimiliki seseorang, ditambah dari pola berpikir yang sepenuhnya menggunakan dan bersifat rasional. Contohnya seorang ahli dalam pengolahan data melakukan kecurangan dalam membuat laporan karena merasa mampu memanipulasi data. b). Disonansi Personal. Faktor ini didorong oleh kebutuhan dan ke- 
pentingan diri, ketergesaan dan keadaan darurat, kekerabatan dan keluarga, keyakinan diri dan mitos, kebiasaan dan budaya, tugas dan jabatan, dan hasrat untuk sukses dan kesenangan. c). Disonansi Sosio Politis. Faktor ini didorong karena munculnya ideologi, ras dan kesukuan, nasionalisme pada diri manusia itu sendiri. Misalnya betapapun dunia pendidikan telah berupaya dan berusaha menanamkan nilai, moral dan norma kebaikan kepada anak didiknya, namun bila pihak pemerintah disisi lain membiarkan semakin leluasanya pornografi, maka kondisi ini sangat berpegaruh pada perkembangan moral. d). Disonansi Bawaan Ilmu Pengetahuan dan Pola Modernisasi. Kemajuan ilmu pengetahuan dan teknologi memiliki implikasi ganda, yaitu bersifat positif dan negatif. Anak usia Taman kanak-kanak saat ini, sangat mudah mengakases apapun yang dia inginkan. Hal ini akan berpengaruh pada masuknya nilainilai keagamaan pada anak tersebut.

\section{Pemahanan Keagamaan Anak Usia 3-4 Tahun}

Perkembangan Keagamaan. Keberminatan anak terhadap agama sudah mulai muncul pada masa rentang usia 3-4 tahun. Akan tetapi, minat terhadap agama ini tidak dapat selalu ditafsirkan bahwa anak mulai menunjukkan sikap rajin beribadah sesuai dengan ritual keagamaan keluarganya. Rasa ingin tahu anak terhadap agama biasanya muncul melalui banyak pertanyaan yang berkaitan dngan agama seperti "apakah Tuhan memikili mata sehingga Dia bisa melihat semua perbuatan yang kita lakukan?" atau "Di manakah Tuhan bertempat tinggal? Atau pertanyaan lain yang mengusik seperti “Apakah Tuhan itu ada?".

Winda Gunarti (2008: 3.19) mengatakan bahwa konsep moral anak tentang agama sangat realistik karena anak menerjemahkan apa yang didengar dan dilihat sesuai dengan apa yang sudah diketahuinya. Bagi anak, Tuhan dapat berwujud, seperti seseorang yang berambut putih, berjanggut putih dan panjang serta berpakaian serba putih. Contoh lainnya, anak mungkin mendeskripsikan sesosok malaikat sebagai makhluk yang berjenis kelamin lakilaki atau perempuan dan baik hati. Kenyataan ini smakin menegaskan bahwa anak usia 3-4 tahun masih berada dalam tahap pemikiran yang egosentris.

Sepanjang periode kehidupannya, seseorang akan melewati tiga tahap perkembangan beragama. Menurut Ernerst Harms, tiga taha- pan perkembangan beragama tersebut, yaitu : 1) Tahap dongeng (the early tale stage); 2) Tahap kenyataan (the early realistic stage); dan 3) Tahap individual (the early individual stage).

Emosi dan fantasai anak sangat dominan mempengaruhi pemahamannya terhadap konsep ketuhanan. Dikatakan tahap dongeng karena anak masih terpengaruh dengan dongeng yang kaya imajinasi. Certa dalam dongeng tersebut kemudian direfleksikan dalam pemahaman keagamaan mereka. Sebagai contoh: seorang anak berusia empat tahun akan mengatakan bahwa Tuhan dalam bayangannya sama seperti matahari karena dia begitu kuat dan selalu ada sewaktu dia bangun dari tidur, sinarnya akan masuk ke dalam diri mereka tanpa disadari.

Berdasarkan tahapan dan karakteristik keagamaan yang dimiliki oleh anak usia 3-4 tahun, maka pengembangan nilai agama sudah seharusnya diterapkan dengan perkembangan tersebut. Ulwan dalam (Gunarti, 2008:3.20) menguraikan lima metode yang dapat dikembangkan untuk mempersiapkan anak agar anak mencapai kematangan dalam nilai agama (Spiritualitas) dan moral, yaitu sebagai berikut:

Pertama, pendidikan dengan keteladanan. Guru dan orang tua merupakan model yang paling baik dalam pandangan anak maka pendidikan dengan memberikan contoh teladan kepada anak merupakan salah satu metode penanaman nilai agama yang efektif. Dengan demikian pendidikan harus menunjukkan perilaku yang jujur, dapat dipercaya serta menjauhkan diri dari perbuatan yang ditentang agama.

Kedua, pendidikan dengan pembiasaan. Pembiasaan merupakan perwujudan praktik nilai-nilai keagamaan melalui kegiatan rutin sehari-hari, seperti mengucapkan salam kepada ibu guru ketika sampai di sekolah dan melafalkan doa sebelum dan ssudah makan.

Ketiga, pendidikan dengan nasihat. Pendidik perlu memberikan bimbingan dan arahan tentang nilai-nilai agama melalui pemberian nasihat. Nasihat yang diberikan agar tidak terkesan menggurui dapat disampaikan dengan menggunakan teknik bercerita.

Keempat, pendidikan dengan memberi perhatian. Pendidik hendaknya senantiasa memperhatikan dan mengawasi spiritual anak dengan mengajak anak mengerjakan kebaikan. Pendidik dapat juga membuka cakrawala berpikir anak tentang makhluk ciptaan Tuhan secara universal, benda hidup dan benda mati, air 
sungai yang mengalir, bunga-bunga yang bermekaran dan jutaan citaan Tuhan lainnya.

Kelima, pendidikan dengan memberi hukuman. Hukuman merupakan pilihan pengembangan anak yang terakhir namun, alangkah baiknya jika penggunaan hukuman tidak dilakukan. Hukuman berkaitan dengan suatu bentuk kerugian yang diterima oleh anak apabila melakukan kesalahan. Merupakan langkah yang arif jika lebih memilih menggunakan metode lainnya yang berdampak positif daripada menekankan pada tingkah laku yang salah dan mengancamnya dengan hukuman.

Faktor yang mempengaruhi perkembangan moral. Hildayani (2008:12.9) mengatakan bahwa ada beberapa faktor yang dapat mempengaruhi perkembangan moral keagamaan pada anak usia dini diantara sebagai beikut :

a). Penggunaan alasan. Orang dewasa (guru dan orang tua) membantu perkembangan moral anak ketika merekamelihat bahwa anak berusaha untuk menyakiti dan menekan orang lain dengan perilakunya. b). Interaksi dengan sebaya. Anak dapat mempelajari banyak hal mengenai moralitas dalam inetraksinya dengan sebaya. Ini terlihat dalam aktivitas kelompok bermain dimanaada isu yang berkaitan dengan kerja sama, berbagi, dan perundingan. c). Contoh tingkah laku oral dan perilaku sosial. Anak terlihat lebih mudah menampilkan perilaku moral dan prososial ketika mereka melihat orang lain yang berperilaku sesuai Moral. Misalnya apabila orang tua bersikap ramah dan menunjukkan perhatian pada orang lain, anaknya pun cenderung bersikap sama. d). Isu-isu dan dilema Moral. Kohlberg mengajukan pendapat bahwa anak mengembangkan kemampuan moral ketika mereka dihadapkan ada dilema moral yang tidak dapat mereka atasi sesuai perkembangan moral mereka. Oleh karena itu, dibutuhkan penalaran dan pemahaman sampai pada akhirnya mereka mendapatkan kemampuan untuk bertingkah laku sesuai dengan perkembangan moral yang lebih tinggi.

\section{Karakteristik Perilaku Keagamaan AUD}

Menurut Badruzaman (2010) pembentukan perilaku ini berfungsi untuk mencapai beberapa hal: (1) Menanamkan pembiasaan sikap dan perilaku yang didasari oleh nilai agama dan moral sehingga anak dapat hidup sesuai dengan nilai-nilai yang dijunjung oleh masyarakat; (2) Membantu anak agar tumbuh menjadi pribadi yang matang dan mandiri; (3) Me- nanamkan budi pekerti yang baik (4) Melatih anak untuk dapat membedakan sikap dan perilaku yang baik dan yang tidak baik sehingga dengan sadar berusaha menghindarkan diri dari perbuatan tercela; (5) Sebagai wahana untuk terciptanya situasi belajar anak yang berlangsung tertib, aktif, dan penuh perhatian; (6) Melatih anak didik untuk mencintai lingkungan yang bersih dan sehat; (7) Menanamkan kebiasaan disiplin dalam kehidupan sehari-hari (budaya bersih, tertib, dan kerjasama).

Ruang lingkup pembentukan perilaku melalui pembiasaan meliputi (1) Berdo'a sebelum dan sesudah kegiatan; (2) Mengucapkan salam bila bertemu dengan orang lain; (3) Tolong menolong sesama teman; (4) Rapi dalam bertindak, berpakaian dan bekerja; (5) Berlatih untuk selalu tertib dan patuh pada peraturan; (6) Tenggang rasa terhadap keadaan orang lain; (7) Berani dan mempunyai rasa ingin tahu yang besar; (8) Merasa puas atas prestasi yang dicapai; (9) Bertanggung Jawab terhadap tugas yang diberikan; (10) Bergotong royong sesama teman; (11) Mencintai tanah air; (12) Mengurus diri sendiri; (13) Menjaga kebersihan lingkungan; (12) Mengendalikan emosi seperti berpisah dengan ibu tanpa menangis; Sabar menunggu giliran; Berhenti bermain pada waktunya; dan lain-lain. (13) Sopan santun meliputi: (a) Mengucapkan terima kasih dengan baik; (b) Meminta tolong dengan baik; dan (14) Menjaga keamanan diri termasuk : (a) Menghindari obat-obatan yang berbahaya; dan (b) Menghindari benda-benda yang berbahaya

\section{PEMBAHASAN}

Taman Kanak-Kanak merupakan lembaga Pendidikan Anak Usia Dini yang berada di bawah dinas pendidikan PAUDNI. Pendidikan di Taman Kanak-Kanak mengajarkan tentang beberapa perkembangan anak usia dini yaitu meliputi pencapaian perkembangan kognitif, afektif, sosial emosi, bahasa, motorik halus dan motorik kasar, seni dan agama.

Salah satu dari materi yang dikembangkan pada Taman Kanak-Kanak adalah penanaman moral nilai-nilai agama yang meliputi keimanan, kepribadian dan kebiasaan ibadah sehari-hari. Materi keimanan mencakup iman kepada Allah swt, iman kepada para malaikat Allat, iman kepada kitab-kitab Allah, iman kepada Rosul-rosul Allah, iman kepada hari akhir, iman kepada qodlo dan qadar. Materi kepribadian mencakup pengenalan diri sendiri se- 
bagai individu, anggota keluarga dan sebagai orang yang beragama. Sedangkan materi kebiasaan beribadah sehari-hari meliputi ibadah mahdoh yaitu seperti sholat, zakat, dan puasa.

Untuk mencapai dari tujuan pendidikan tersebut Taman Kanak-Kanak membuat layanan konseling Islami diantara layanan tersebut mengajarkan kepada para siswa untuk memiliki keimanan yang baik, kepribadian yang baik dan kebiasaan beribadah yang baik pula.

Layanan konseling Islami di Taman Kanak-Kanak belum terprogram secara khusus, tetapi masih tergabung dalam pendidikan keagamaan. Program keagamaan yang sudah dilakukan adalah membiasakan para siswa berjamaah di musholah, diajarkan membaca alqur'an, diajarkan bersedekah, diajarkan cara berwudlu yang sesuai dengan perintah Rosulullah saw.

Adapun sistem pembelajaran di Taman Kanak-Kanak menggunakan kurikulum terpa$\mathrm{du}$, antara kurikulum nasional (sesuai dengan undang-undang PAUDNI) dan kurikulum lokal. Sehingga disebut Taman Kanak-Kanak Islam Terpadu. Waktu belajar di Taman Kanak-Kanak Islam Terpadu Kharisma Darussalam Kota baru Karawang di mulai dari pukul 08.00 sampai dengan 16.00.

\section{Upaya yang sudah dilakukan oleh Guru dan Orang Tua Taman Kanak-Kanak dalam pe- nanaman moral nilai-nilai keagamaan.}

Perlakuan Guru. Upaya yang pernah dilakukan oleh guru Taman Kanak-Kanak dalam mengajarkan nilai-nilai keagamaan di sekolah adalah dengan memasukan nilai-nilai moral keagamaan, dalam RKH (Rencana Kegiatan Harian) disusun terlebih dahulu, kemudian menyusun media pengajarannya dalam bentuk visual (yang mudah dilihat oleh para siswa). Setelah itu guru mengajarkannya di dalam kelas.

Penanaman moral yang selama ini dilakukan guru berupa kebiasaan sehari-hari seperti setiap pagi hari murid di suruh mengucapkan salam, kemudian berdo'a sebelum belajar, kemudian membaca salah satu surat dalam alqur'an, disamping itu pula guru selalu bercerita tentang para rosul, para sahabat nabi, para aulia dan orang-orang sholeh dalam cerita islam.

Perlakuan Orang Tua. Upaya yang dilakukan oleh orang tua dari siswa Taman KanakKanak adalah mengajarkan mengkaji alqur'an dengan cara belajar membaca, menulis, dan memahami makhorijil hurufnya. Disamping itu pula orang tua juga membiasakan anak-anaknya untuk melaksanakan ibadah sehari - hari seperti sholat lima waktu, puasa, dan mengenal perbuatan baik.

Kendala yang pernah dialami oleh Guru dan Orang Tua AUD dalam penanaman moral nilai-nilai keagamaan.

Kendala yang dialami Guru. Kendala yang dialami oleh Guru dalam mengajarkan penanaman moral nilai-nilai keagamaan pada siswa Taman Kanak-Kanak adalah kekurangmampuan guru dalam mengenal materi keagamaan yang tepat bagi para siswa Taman Kanak-Kanak.

Keterbatasan ini lebih disebabkan oleh faktor keterbatasan kemampuan guru dalam memahami agama dan perkembangan psikologis siswa usia anak usia dini (PAUD). Hal ini terlihat dari ketidaksesuaian antara materi yang diajarkan oleh guru dengan karakteristik siswa anak usia dini, sehingga mereka banyak yang masih belum paham bahkan ketika proses belajar mengajar anak masih ribut di sana sini.

Kendala yang dialami Orang Tua. Adapun kendala yang di alami oleh orang tua dari siswa Taman Kanak-Kanak adalah faktor kesibukan dari orang tua. Banyaak dari orang tua siswa tersebut yang bapak dan ibunya bekerja dari pari (pukul 7) sampai sore (pukul 6) sehingga intensitas komunikasi antara orang tua dan anak sangat rendah, akhirnya orang tua kurang bisa memberikan penanaman moral nilainilai keagamaan secara maksimal.

Disamping itu pula kendala lainnya adalah masih banyak orang tua yang kurang memahami tentang materi keagamaan seperti membaca alqur'an, ilmu fiqih, materi keimanan dan tentang sholat. Hal ini berpengaruh terhadap perkembangan moral nilai-nilai keagamaan anak.

Upaya yang dilakukan oleh guru dan Orang Tua AUD dalam penanaman moral nilainilai keagamaan.

Upaya yang dilakukan antara orang tua dan guru dalam meningkatkan penanaman moral nilai-nilai keagamaan siswa Taman KanakKanak adalah dengan membentuk konsolidasi antara orang tua dan guru. Konsolidasi tersebut dilakukan selama satu kali dalam sebulan. Hal ini dimaksudkan untuk memberikan koreksi antara apa yang dilakukan orang tua dan apa yang dilakukan oleh guru. 


\section{Implikasi pada Layanan Konseling Islami}

Implikasi dalam penelitian ini adalah lahirnya layanan konseling Islami khususnya untuk anak usia dini yaitu berkisaran usia $1-6$ tahun. Adapun bentuk layanan konselingnya sebagai berikut:

\begin{tabular}{|c|c|c|c|c|}
\hline No & Topik & Materi & Tujuan & Kegiatan \\
\hline \multirow[t]{6}{*}{1} & Keimanan & $\begin{array}{l}\text { Kepada } \\
\text { Allah Swt }\end{array}$ & $\begin{array}{l}\text { AUD dapat } \\
\text { menjalankan } \\
\text { perintah Allah } \\
\text { Swt }\end{array}$ & $\begin{array}{l}\text { Memperkenal- } \\
\text { kan tentang be- } \\
\text { berapa perintah } \\
\text { Allah }\end{array}$ \\
\hline & & $\begin{array}{l}\text { Kepada } \\
\text { malaikat }\end{array}$ & $\begin{array}{l}\text { AUD dapat } \\
\text { meyakini ada- } \\
\text { nya makhluk } \\
\text { gaib }\end{array}$ & $\begin{array}{l}\text { Menjelaskan tu- } \\
\text { gas pokok ma- } \\
\text { laikat Allah }\end{array}$ \\
\hline & & $\begin{array}{l}\text { Kepada } \\
\text { Kitab }\end{array}$ & $\begin{array}{l}\text { AUD dapat } \\
\text { mengimani a- } \\
\text { danya kitab } \\
\text { Allah }\end{array}$ & $\begin{array}{l}\text { Memperkenal- } \\
\text { kan kitab-kitab } \\
\text { Allah }\end{array}$ \\
\hline & & $\begin{array}{l}\text { Kepada } \\
\text { Rosul }\end{array}$ & $\begin{array}{l}\text { AUD dapat } \\
\text { mengikuti a- } \\
\text { jaran para ro- } \\
\text { sul }\end{array}$ & $\begin{array}{l}\text { Memperkenal- } \\
\text { kan Rosul-rosul } \\
\text { yang wajib di } \\
\text { ketahui }\end{array}$ \\
\hline & & $\begin{array}{l}\text { Kepada hari } \\
\text { akhir }\end{array}$ & $\begin{array}{l}\text { AUD dapat } \\
\text { menyakini a- } \\
\text { danya kehi- } \\
\text { dupan di ak- } \\
\text { hirat }\end{array}$ & $\begin{array}{l}\text { Memberikan } \\
\text { contoh tentang } \\
\text { keberadaan hari } \\
\text { akhir dg melihat } \\
\text { orang yg mati }\end{array}$ \\
\hline & & $\begin{array}{l}\text { Kepada qodo } \\
\text { dan qadar }\end{array}$ & $\begin{array}{l}\text { AUD dapat } \\
\text { mengimani } \\
\text { keberadaan } \\
\text { qodo dan qa- } \\
\text { dar }\end{array}$ & $\begin{array}{l}\text { Memberi con- } \\
\text { toh tentang ke- } \\
\text { jadian diseki- } \\
\text { tarnya ada yg } \\
\text { mengatur }\end{array}$ \\
\hline \multirow[t]{3}{*}{2} & Kepribadian & $\begin{array}{l}\text { Mengenal } \\
\text { diri }\end{array}$ & $\begin{array}{l}\text { AUD dapat } \\
\text { menyebutkan } \\
\text { nama dan } \\
\text { asalnya }\end{array}$ & $\begin{array}{l}\text { Guru memberi } \\
\text { contoh tentang } \\
\text { dirinya \& siswa } \\
\text { berlatih }\end{array}$ \\
\hline & & $\begin{array}{l}\text { Mengenal } \\
\text { keluarga }\end{array}$ & $\begin{array}{l}\text { AUD dapat } \\
\text { menyebutkan } \\
\text { anggota kelu- } \\
\text { arganya }\end{array}$ & $\begin{array}{l}\text { Guru mengajak } \\
\text { siswa untuk } \\
\text { berkunjung ke } \\
\text { keluarganya }\end{array}$ \\
\hline & & $\begin{array}{l}\text { Sebagai } \\
\text { orang yang } \\
\text { beragama }\end{array}$ & $\begin{array}{l}\text { AUD dapat } \\
\text { menjalankan } \\
\text { kewajiban o- } \\
\text { rang yang } \\
\text { beragama }\end{array}$ & $\begin{array}{l}\text { Guru menjelas- } \\
\text { kan kewajiban } \\
\text { orang yang ber- } \\
\text { agama seperti } \\
\text { sholat, puasa. }\end{array}$ \\
\hline \multirow[t]{3}{*}{3.} & $\begin{array}{l}\text { Kebiasaan } \\
\text { Ibadah }\end{array}$ & Sholat & $\begin{array}{l}\text { AUD dapat } \\
\text { menjalankan } \\
\text { sholat Wajib }\end{array}$ & $\begin{array}{l}\text { Guru membia- } \\
\text { sakan anak sho- } \\
\text { lat di masjid }\end{array}$ \\
\hline & & Puasa & $\begin{array}{l}\text { AUD dapat } \\
\text { melakukan } \\
\text { Puasa Wajib }\end{array}$ & $\begin{array}{l}\text { Anak dilatih un- } \\
\text { tuk berpuasa se- } \\
\text { harian penuh }\end{array}$ \\
\hline & & Wudlu & $\begin{array}{l}\text { AUD dapat } \\
\text { melakukan } \\
\text { wudlu dengan } \\
\text { benar }\end{array}$ & $\begin{array}{l}\text { Guru mempe- } \\
\text { ragaan cara ber- } \\
\text { wudu di depan } \\
\text { siswa }\end{array}$ \\
\hline
\end{tabular}

\section{SIMPULAN}

Menurut Imam Magib yang dikutip oleh Syamsu Yusuf (2008) bahwa konseling Islami mempunyai beberapa prinsip, yaitu: (a) kerahasiahan (confidentiality); (b) kepercayaan (tr$u s t$ ); (c) kecintaan berbuat baik kepada orang lain; (d) mengembangkan sikap persaudaraan, atau menciptakan sikap damai diantara sesama; (e) memperhatikan masalah-masalah kaum muslimin; (f) memiliki kebiasaan untuk mendengarkan yang baik; (g) memahami budaya orang lain; (h) adanya kerjasama antara ulama dan konselor; (i) memiliki kesadaran hukum; (j) bertujuan untuk meningkatkan keimanan dan ketaqwaan kepada Allah swt, dan (k) menjadikan Nabi Muhammad SAW sebagai model (Uswah hasanah) utama dalam kehidupan, khususnya menyangkut sikap kasih sayangnya kepada orang lain.

Konseling Islami pada anak usia dini (AUD) adalah menekankan pada tiga kemampuan yaitu (1) Keimanan yang meliputi iman kepada Allah, kepada malaikat, kepada Kitab, kepada rosul, kepada hari akhir, kepada qodo dan qadar; (2) kepribadian, yang meliputi: mengenal diri sendiri, mengenal keluarganya, memahami kewajiban sebagai orang yang beragama; dan (3) membiasaan beribadah, yang meliputi: melakukan sholat wajib, menjalankan puasa wajib dan mampu melakukan wudlu dengan benar.

Adapun strategi layanannya adalah dengan 1) uswatun hasanah; 2) membiasakan anak untuk mengikuti materi keagamaan; 3 ) terintegrasi dalam program sekolah; 4) tabayyun; dan al-hikmah / memberikan wawasan yang luas tentang materi keagamaan.

\section{DAFTAR PUSTAKA}

Abdullah, Fathi Adil. (2007). Pahami Anak Anda, Anda akan Sukses Mendidiknya. Pustaka al-Kautsar. Jakarta Timur.

Ali, Daud Muhammad. (1998). Pendidikan Agama Islam. Jakarta: Rajawali Pers.

Amin, Sidik. (2000). Tata Cata Sholat. Bandung: Persis.

Aripin. (2000). Manusia dan Pendidikan. Jakarta : Al-Husna Zikra.

Azra, Azumardi. (1996). Pendidikan dalam Keluarga Muslim. Jakarta: Rajawali Pers.

Chance, Paul. (1994). Learning and Behaviour. California: Brooks/Cole Pub Comp.

Departemen Agama RI. (1971). Al-Qur'an dan Terjemahnya. Jakarta.

Hawari, Dadang. (1996). Al-Qur'an Ilmu Kedokteran Jiwa dan Kesehatan Jiwa. Yogyakarta: PT. Dana Bhakti Prima

Hildayani, Rini. Dkk (2008). Psikologi Perkembangan Anak. Penerbit Universitas Terbuka. Jakarta

Hurlock, Elizabet. (1950). Child Development. New York. McGraw Hill Book Company. Inc.

Langgulung, Hasan. (1995). Manusia dan Pendidikan Suatu Analisa Psikologi dan Pendidikan. Jakarta: Al-Husna Zikra. 
Moloeng, LJ. (1989). Metodologi Penelitian dalam Pendidikan. Bandung: Rosdakarya.

Mujib, A. (1999). Fitrah dan Kepribadian Islam. Jakarta: Darul Falah.

Rakhmat, Jalaluddin dan Gandaatmaja, Mukhtar. (1994). Keluarga Muslim dalam Masyarakat Modern. Bandung: Rosda Karya.

Ridwan. (1988). Metodologi Penelitian. Bandung: Rineka Cipta.

Sabiq, Sayyid. (1996). Fikih Sunnah. Bandung: PT. Al-Ma'arif.
Satibi, Otib. Dkk (2008). Metode Pengembangan Moral dan Nilai-Nilai Agama. Penerbit Universitas Terbuka. Jakarta

Syamsi, Hasan Pasya. (2009). Ibu, Bimbing Aku Menjadi Anak Sholeh. Pustaka Rahmat. Bandung.

Tafsir, Ahmad. (1987). Ilmu Pendidikan Islam Dalam Perspektif Islam. Bandung: Remaja Rosdakarya.

Ulwan, Nashih, Abdullah. (1995). Pendidikan Anak dalam Islam. Jakarta: Pustaka Amami.

Yusuf, Syamsu LN. (2000). Psikologi Perkembangan Anak dan Remaja. Bandung: Rosda Karya. 